\title{
Analysis of Human Error in Healthcare Industry: an Indian Perspective
}

\author{
R.K.A.Bhalaji, S. Bathrinath, S. Saravanasankar
}

\begin{abstract}
In healthcare sector, employing human knowledge, on a larger scale, in the decision making process in identifying the risk sources is very common, and often the human error in the process results in adverse effects of unrecognized risks. Hence, the impact of human error in employing the human knowledge remains a major problem. To minimize the human error a fuzzy based risk assessment method using Ranked Risk Breakdown Structure (RRBS) model is proposed in this work. The proposed method is able to rank the risk resources on the basis of a risk score generating mechanism based on the probability of occurrence of risk and outcome of the risk. By recognizing the high ranking risk resources, that is, the risk drivers at higher levels of seriousness/severity, this fuzzy based methodology nullify the existing common human errors. The proposed methodology is validated with the actual past data of one decade period, the occurrence of risk and its effect in a healthcare industry situated in an urban city of India. The results of the experimentation reveal that the proposed methodology can be successfully implemented in all other industries in healthcare sector to minimize the human error in risk recognition. The suggested model is helpful for industrial managers/practitioners to tackle risk factors related with complex works.
\end{abstract}

Keywords: Fuzzy set, Risk assessment, RRBS.

\section{INTRODUCTION}

\section{C} urrently, the healthcare sector has increased enormously due to quick monetary growth globally. Though execution of healthcare in metropolitan cities is extremely engaging it is also very risky, modest and dynamic due to intricate nearby environments such as schools, living apartments, restaurants, super markets and so on. Human error is a key issue in the industry, bringing about many thousand preventable deaths and over a million of critical unnecessary wounds annually. Risks related to the industry could get unfavourable results in terms of decision error, equipment malfunction and unexpected death. The word 'risk' can be comprehended as the potential for difficulties and issues regarding conclusion of the project errand and the accomplishment of project objective [1]. Risk is intrinsic in each work under implementation; it cannot be completely removed; somewhat, it can alleviate the effects that will probably hinder the achievement of a work. If possible risk

Revised Manuscript Received on December 05, 2019.

* Correspondence Author

R.K.A.Bhalaji, Department of mechancical engineering, Kalasalingam Academy of research and education, Krishnankoil-626126, India. Email: bhalaji28@gmail.com

S.Bathrinath*, Department of mechancical engineering, Kalasalingam Academy of research and education, Krishnankoil-626126, India. Email: bathri@gmail.com

S.Saravanasankar, Department of mechancical engineering, Kalasalingam Academy of research and education, Krishnankoil-626126, India. Email: ssaravanasankar@klu.ac.in factors are prudently recognized, evaluated and checked at a nascent stage; the likelihood of on-time and financial fulfilment of the task can be enlarged greatly.

\section{STATE OF ART AND PROBLEM FORMULATION}

Dhillon [2] presented the methodology for carrying out human dependability and error investigation in the healthcare sector. The result showed that repetitive error can be avoided in future by adopting the methodology. Flin et al. [3] conducted quantitative analyses of the wellbeing atmosphere in the healthcare sector to check psychometric aspects in this area. The findings suggest that more attention be given to psychometric aspects in healthcare security atmosphere devices as they are used as a part of huge scale studies by healthcare associations. Gawanmeh et al. [4] evaluated and tested few healthcare data frameworks are a few open issues and difficulties in the healthcare industries. From the above study, it was observed that a combination of new advancements, for example, cloud frameworks and enormous information, into healthcare frameworks lead to challenging issues. Lin et al. [5] examined and construct an evaluation replica for human dependability of medical gadgets to enhance the security by using FMEA (failure mode and effective analysis) and Fuzzy semantic theory. The outcome showed that management, interaction and teamwork could lead to more no of mishaps. Reason [6] analyzed human faults in healthcare sector by using different methods such as individual and framework methods. It was observed that high dependability associations are prime causes for the framework method. They foresee the nastiest and manage every level of the management.

Muthuperumal et al. [7] performed the analysis on resolving (GTrFN) generalized trapezoidal fuzzy no's using ranking method. The result showed that suggested technique with a descriptive arithmetical model to acquire the resolution to the trapezoidal fuzzy no's using ranking method. Kumar et al. [8] suggested the methodology for the ranking of generalized trapezoidal fuzzy no's (GTrFN). The outcome indicates that this methodology gives the accurate ranking of generalized trapezoidal fuzzy no's and contrasted with various present methodologies. Their review depicts that partial tries were made to found a complete risk appraisal method, through a fuzzy decision-making perspective, related to healthcare ventures. This aspect has to be included for different problems like doubt in individual evaluation, decision maker's psychological mindsets (negative, positive and reasonable etc.) in risk appraisal progress. It is important to improve a risk alleviation strategy ordinarily needed to effectively administer of healthcare venture risks. Hence, a well-organized risk evaluation structure is proposed 
in this paper for efficient administration of healthcare venture risks using fuzzy based decision making notions. The suggested method use 'Circumcenter of Centroid' technique [9] to measure the equal crisp score against fuzzy risk rating for specific risk drivers. Moreover, all recognized drivers were categorized into various groups dependent on their level of seriousness; finally, an activity prerequisite strategy was recommended for effectual administration and consequent alleviation of healthcare venture risks was recommended.

In this paper, risk appraisal shadowed by classification of various risk resources is considered to a decision making job. Various specialists have been consulted to express their decisions with regard to event probability and the outcome through semantic terms. As semantic assessment data has some doubt (vagueness and ambiguity); with the specific end goal to beat, fuzzy set theory has been investigated in this work. The risk evaluation has been performed through the investigation of fuzzy arithmetic instead of seeking past information and probabilistic theory of risks. Dependent on surveys and business intelligence, a structure system (called Ranked risk-breakdown structure) comprising of possible risk measurements (ensued by risk drivers) linked to an instance healthcare division is constructed. Decision makers were asked for their views on probability of event and outcome with every risk driver using an assumed semantic scale and then they have been changed to fuzzy numbers. Throughout investigation of fuzzy operational guidelines, the risk's seriousness has been figured. Distinctive risk resources are sorted into various seriousness extents. Activity prerequisite strategies have also been recommended to alleviate probability of recognized risks.

\section{NOTION OF RISK ASSESSMENT}

As per British Standards Institution [10], risk appraisal is described as the method of assessing a risk emerging from a peril, considering the sufficiency of any current controls, and choosing whether the risk is satisfactory or necessitates control activities. In this work, risk is portrayed as a component of dual constraints (a) probability, which is the likelihood of an unwanted event and (b) effect, which is the level of severity, when an unwanted entity happens. Thus, using a numerical depiction, risk score is computed as:

$$
R=P \times E
$$

where is the risk score (level of risk), inside; the probability of risk happening inside; the level of effect of the risk inside where more esteem reveals a higher effect

\section{FUZZY SET THEORY: RANKING OF FUZZY NUMBERS}

The fuzzy set notion was first initiated by Zadeh [11] with the aim of managing ambiguity in human consideration. Fuzzy set theory can scientifically signify doubt and ambiguity, and give formal methods to manage subjectivity innate to decision making issues. In decision making, different kinds of fuzzy no's, for example, triangular, trapezoidal, Gaussian fuzzy numbers (membership functions) are used to translate semantic information into quantifiable shape. Trapezoidal fuzzy numbers are used due to their ease in scientific portrayal and simple calculation. A trapezoidal fuzzy number can be signified in the shape which is the utmost general category of fuzzy no's with linear membership functions. Hence, due to its nonspecific property, these classes of fuzzy numbers are typically used to demonstrate ambiguity in logical and practical engineering issues, instead of the category of triangular fuzzy numbers.

Rao and Shankar [12] showed an enhanced positioning technique to arranging fuzzy no's using 'Circumference of Centroids'. This technique gives a numerical expression to position fuzzy numbers dependent on their crispy notch. This notion has been investigated in this work for ranking the diverse risk resources in accord to seriousness levels. The fundamental notion of Circumference of Centroids is stated below.

Deliberate a generalized $\operatorname{TrFN} E=(p, q, r, s ; v)$. Centroids of the three flat figures are $C_{1}=((a+2 b) / 3, v / 3), C_{2}=((b+c) / 2, v / 2)$ and $C_{3}=((2 c+d) / 3, v / 3)$, individually. Equation of the line $C_{1} C_{2}$ is $Z=v / 3$ and $C_{2}$ does not remain on the line $C_{1} C_{3}$. Then, $C_{1}, C_{2}$ and $C_{3}$ are non collinear and frame one triangle.

The circumcenter $K_{E}\left(M_{o}, N_{o}\right)$ of the triangle with apexes $C_{1}, C_{2}$ and $C_{3}$ of the general $\operatorname{TrFN}$ of $E=(p, q, r, s ; v)$ are described as

$K_{E}\left(M_{o}, N_{o}\right)=\left(\frac{p+2 q+2 r+s}{6}, \frac{(2 p+q-3 r)(2 s+r-3 q)+5 v^{2}}{12 v}\right)$

As an exceptional case, for $\operatorname{TrFN}$, that is the circumference of centroid is specified by

$K_{E}\left(M_{o}, N_{o}\right)=\left(\frac{p+q+4 s}{6}, \frac{4(p-q)(s-q)+5 v^{2}}{12 v}\right)$

The positioning occasion of $\operatorname{TrFN} E=(p, q, r, s ; v)$, which plots the arrangement of every single fuzzy number to an arrangement of actual numbers is characterized as:

$$
J(E)=\sqrt{\mathrm{Mo}^{2}+\mathrm{No}^{2}}
$$

Where $J(E)$ is the Euclidean space from the circumcenter of the centroids and the original point.

\section{PROPOSED METHODOLOGY}

Step 1: Recognition of possible risk factors to frame a ranked risk breakdown framework.

Step 2: Choosing of suitable semantic scale to help specialist teams to articulating both probability of event and effect of risks (individual assessment).

Step 3: Semantic statistics (related to probability of event and effect of risk against every risk driver) are gathered from specialists through a group review. Subsequently, semantic statistics are converted to proper $\mathrm{TrFN}$ in accord with an assumed

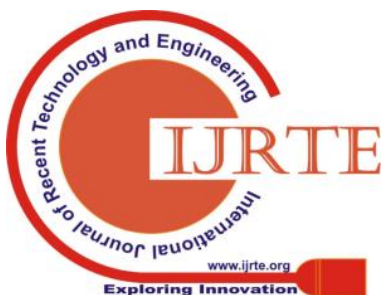


fuzzy scale set by the administration. A specialist team's pulled-opinion is needed to use 'Fuzzy aggregation regulation'.

Step 4: Aggregated fuzzy inclinations are calculated utilizing fuzzy aggregation regulation. The Fuzzy risk score of every risk driver is computed by multiplying 'aggregated fuzzy probability of event' with the 'aggregated fuzzy risk effect'.

Step 5: Comparing crisp esteem against fuzzy risk score related to every risk driver is computed using the technique of 'Circumference of Centroids'. Also, various risk factors are positioned dependent on their crisp scores (pointer of the level of seriousness).

Step 6: Risk drivers are classified into different extents of seriousness dependent on the notion of risk matrix.

Step 7: Lastly, an activity prerequisite strategy is recommended for risk drivers be owned by various seriousness levels.

\section{CASE EMPIRICAL STUDY}

The case study have been conducted based on the data collected from the healthcare industry in one of the metropolitan cities in India, to understand the application procedures of the proposed RRBS model. It is observed that healthcare sector is budding area in metropolitan city also the foreign investment have been huge in this sector. The new healthcare industries are started with advanced technologies in the different places of the city. This leads to the accumulation of more human error in the healthcare domain. Hence to address in this context is very important for the development of healthcare industries. It is also understood that healthcare works are getting delayed in different places of the city because of the risks involved in this sector. The outcome of this research will definitely help the healthcare managers to understand the various risks involved in this domain by implementing suitable control measures to reduce the seriousness of the risks.

\section{RESULT AND DISCUSSIONS}

An experimental investigation on essential problems of risks and their control actions has been introduced with regard to a human error in the Healthcare industry. The study has evaluated general risk by deliberating 17 possible risk drivers and articulated consequently risk management strategy to alleviating or managing risks to human error. Clearly, successful risk administration needs an incorporated system comprising risk recognition, risk valuation and risk extenuation. A ranked risk breakdown structure (RRBS) has been suggested in this paper. Seventeen possible risk drivers from 5 vital risk elements like Planning, Temporary person related functions, Observation, Interpretation and Permanent person related functions have been recognized through the review of past writings and also by seeing specialist proposals. The sole involvement of the existing work has been to express an effectual fuzzy MCDM method to evaluate the level of risk of every recognized risk drivers related to the undertaking. The 'Circumcenter of Centroids' technique has been discovered productive for computing 'crisp' scores against fuzzy risk scores of different risk drivers to aid risk administration. The fuzzy notion has enables changing semantic information against probability and effect (of risk) into a fuzzy score. Moreover, the use of fuzzy set theory has effectively handled the doubt and ambiguity emerging from the specialist's view amidst the individual decision process. It is noticed that calculation of crisp risk scores has aided to observe the level of seriousness of risk that requires regulation for the successful implementation in the healthcare industry. Risk drivers with high severity level ought to be promptly regulated. The additional involvement of this research is in suggesting an incorporated risk administration strategy for recognizing possible risk drivers at various levels of seriousness and recommend fundamental control activities necessary to reduce human error in the healthcare industry. This provides rules for project chiefs to govern, observe, and handle risks related to the health care industry successfully.

\section{CONCLUSION}

Effectual risk administration in healthcare requires a dependable risk assessment and risk action arranging ensued by the following application. The suggested risk appraisal method is seen as feasible and dependable when contrasted with the customary statistical techniques as it uses specialist risk insights subjectively instead of in impartial mode. In this paper, RRBS model using fuzzy set theory has been applied in risk evaluation, for the purpose of rating the risk effects and the probability of the event in comparing each risk drivers with another with the help of decision makers. The apparent human risks in health care might be displayed without difficulty by the created ranked framework. General job risk has been computed due to typically preserving specific risk score esteems (of recognized risk drivers). The paper has used the 'Circumcenter of Centroids' technique to measure risk score as 'equal' crisp result. Also, used specialist Psychological mindsets (like negative, positive and reasonable) to analyze dependability of risk evaluation outcomes. Moreover, this paper has investigated the risk matrix notion, discovered to be effectual in classifying different risk drivers into various levels of seriousness. From among seventeen risk drivers (under five risk elements), the subsequent six risk drivers viz. Psychological stress (H25), Inadequate plan (H11), Memory failure (H21), Faulty diagnosis (H41), Physiological stress (H24) and Malfunction of equipment (H43) have been discovered as being extremely critical regarding human error in the healthcare industry.

\section{APPENDIX}

Table- I: Ranked rick breakdown structure for an instance healthcare sector

\begin{tabular}{|l|l|}
\hline Risk Dimensions $\left(\mathbf{W}_{\mathbf{i}}\right)$ & Risk factors $\left(\mathbf{H}_{\mathbf{i j}}\right)$ \\
\hline Planning $\left(\mathrm{W}_{1}\right)$ & Inadequate plan $\left(\mathrm{H}_{11}\right)$ \\
\cline { 2 - 2 } & Priority error $\left(\mathrm{H}_{12}\right)$ \\
\hline \multirow{3}{*}{$\begin{array}{l}\text { Temporary person related } \\
\text { functions }\left(\mathrm{W}_{2}\right)\end{array}$} & Memory Failure $\left(\mathrm{H}_{21}\right)$ \\
\cline { 2 - 2 } & Performance Variability $\left(\mathrm{H}_{22}\right)$ \\
\cline { 2 - 2 } & Fear $\left(\mathrm{H}_{23}\right)$ \\
\cline { 2 - 2 } & Physiological stress $\left(\mathrm{H}_{24}\right)$ \\
\cline { 2 - 2 } & Psychological stress $\left(\mathrm{H}_{25}\right)$ \\
\hline
\end{tabular}




\begin{tabular}{|l|l|}
\hline Observation $\left(\mathrm{W}_{3}\right)$ & $\left(\mathrm{H}_{31}\right)$ \\
\cline { 2 - 2 } & \\
\cline { 2 - 2 } & Wrong identification $\left(\mathrm{H}_{32}\right)$ \\
\cline { 2 - 2 } & False observation $\left(\mathrm{H}_{33}\right)$ \\
\hline Interpretation $\left(\mathrm{W}_{4}\right)$ & Faulty behavior $\left(\mathrm{H}_{41}\right)$ \\
\cline { 2 - 2 } & Medication errors $\left(\mathrm{H}_{42}\right)$ \\
\cline { 2 - 2 } & Malfunction of equipment's $\left(\mathrm{H}_{43}\right)$ \\
\cline { 2 - 2 } & Decision error $\left(\mathrm{H}_{44}\right)$ \\
\cline { 2 - 2 } & Incorrect procedure of work $\left(\mathrm{H}_{45}\right)$ \\
\hline functions $\left(\mathrm{W}_{5}\right)$ & Cognitive style $\left(\mathrm{H}_{51}\right)$ \\
\cline { 2 - 2 } & Functional Impairment $\left(\mathrm{H}_{52}\right)$ \\
\hline
\end{tabular}

Table- II: Seven point fuzzy semantic scale for evaluating probability of event

\begin{tabular}{|l|l|l|}
\hline Probability & Explanation & Fuzzy No \\
\hline $\begin{array}{l}\text { Absolutely } \\
\text { Certain (AC) }\end{array}$ & $\begin{array}{l}\text { Anticipated what would happen } \\
\text { with outright assurance }\end{array}$ & $(0.8,0.9,1,1 ; 1)$ \\
\hline $\begin{array}{l}\text { Very Frequent } \\
\text { VF) }\end{array}$ & Much expectation of happening & $\begin{array}{l}(0.7,0.8,0.8,0.9 ; \\
1)\end{array}$ \\
\hline Frequent (F) & Liable to happen often & $\begin{array}{l}(0.5,0.6,0.7,0.8 ; \\
1)\end{array}$ \\
\hline Probable (P) & $\begin{array}{l}\text { Liable to happen a few times in the } \\
\text { life of the process }\end{array}$ & $\begin{array}{l}(0.4,0.5,0.5,0.6 ; \\
1)\end{array}$ \\
\hline Occasional (O) & $\begin{array}{l}\text { Liable to happen once in the life of } \\
\text { the process }\end{array}$ & $\begin{array}{l}(0.2,0.3,0.4,0.5 ; \\
1)\end{array}$ \\
\hline Rare (R) & $\begin{array}{l}\text { Improbable, yet possible to happen } \\
\text { sometime in the life of the process }\end{array}$ & $\begin{array}{l}(0.1,0.2,0.2,0.3 ; \\
1)\end{array}$ \\
\hline Very Rare (VR) & $\begin{array}{l}\text { Impossible that the likelihood of } \\
\text { event is insignificant }\end{array}$ & $(0,0,0.1,0.2 ; 1)$ \\
\hline
\end{tabular}

Table- III: Five point fuzzy semantic scale to evaluate effect (Outcome of risk)

\begin{tabular}{|l|l|}
\hline Effect & Fuzzy Number \\
\hline Very High $(\mathrm{VH})$ & $(0.7,0.8,0.9,1 ; 1)$ \\
\hline High $(\mathrm{H})$ & $(0.5,0.6,0.7,0.8 ;$ \\
& $1)$ \\
\hline Moderate $(\mathrm{M})$ & $(0.3,0.4,0.5,0.6 ;$ \\
& $1)$ \\
\hline Low (L) & $(0.1,0.2,0.3,0.4 ;$ \\
& $1)$ \\
\hline Very Low (VL) & $(0,0.1,0.2,0.3 ; 1)$ \\
\hline
\end{tabular}

Table- IV: Probability of event (P) for specific risk drivers as per the individual decisions of the five specialists

\begin{tabular}{|l|l|l|l|l|l|}
\hline $\mathbf{H}_{\mathbf{i j}}$ & $\mathbf{V}_{\mathbf{1}}$ & $\mathbf{V}_{\mathbf{2}}$ & $\mathbf{V}_{\mathbf{3}}$ & $\mathbf{V}_{\mathbf{4}}$ & $\mathbf{V}_{\mathbf{5}}$ \\
\hline $\mathrm{H}_{11}$ & F & F & VF & F & F \\
\hline $\mathrm{H}_{12}$ & O & O & R & O & O \\
\hline $\mathrm{H}_{21}$ & F & F & F & VF & VF \\
\hline $\mathrm{H}_{22}$ & P & P & P & O & P \\
\hline $\mathrm{H}_{23}$ & P & F & F & F & P \\
\hline $\mathrm{H}_{24}$ & P & P & F & F & P \\
\hline $\mathrm{H}_{25}$ & F & F & F & P & P \\
\hline $\mathrm{H}_{31}$ & O & P & P & O & P \\
\hline $\mathrm{H}_{32}$ & P & O & P & P & P \\
\hline $\mathrm{H}_{33}$ & P & P & O & O & O \\
\hline $\mathrm{H}_{41}$ & P & P & F & F & P \\
\hline $\mathrm{H}_{42}$ & P & P & P & O & P \\
\hline $\mathrm{H}_{43}$ & P & F & F & F & P \\
\hline $\mathrm{H}_{44}$ & O & O & P & P & P \\
\hline $\mathrm{H}_{45}$ & R & O & O & P & P \\
\hline $\mathrm{H}_{51}$ & O & O & R & R & R \\
\hline $\mathrm{H}_{52}$ & R & R & O & R & R \\
\hline \multicolumn{7}{|l}{}
\end{tabular}

Table- V: Effect of risk (E) for specific risk drivers as per the individual decision of the five specialists

\begin{tabular}{|l|l|l|l|l|l|}
\hline $\mathbf{H}_{\mathbf{i j}}$ & $\mathbf{V}_{\mathbf{1}}$ & $\mathbf{V}_{\mathbf{2}}$ & $\mathbf{V}_{\mathbf{3}}$ & $\mathbf{V}_{\mathbf{4}}$ & $\mathbf{V}_{\mathbf{5}}$ \\
\hline $\mathrm{H}_{11}$ & H & H & M & M & H \\
\hline $\mathrm{H}_{12}$ & L & M & L & L & M \\
\hline $\mathrm{H}_{21}$ & M & H & H & M & M \\
\hline $\mathrm{H}_{22}$ & M & M & M & L & M \\
\hline $\mathrm{H}_{23}$ & H & M & H & M & H \\
\hline $\mathrm{H}_{24}$ & M & M & M & H & M \\
\hline $\mathrm{H}_{25}$ & H & VH & VH & H & H \\
\hline $\mathrm{H}_{31}$ & L & M & M & L & L \\
\hline $\mathrm{H}_{32}$ & M & M & L & L & M \\
\hline $\mathrm{H}_{33}$ & L & L & L & L & M \\
\hline $\mathrm{H}_{41}$ & H & H & H & M & H \\
\hline $\mathrm{H}_{42}$ & M & M & H & H & M \\
\hline $\mathrm{H}_{43}$ & M & M & M & H & M \\
\hline $\mathrm{H}_{44}$ & M & M & H & H & M \\
\hline $\mathrm{H}_{45}$ & H & H & M & M & M \\
\hline $\mathrm{H}_{51}$ & L & L & L & M & M \\
\hline $\mathrm{H}_{52}$ & M & M & L & M & L \\
\hline
\end{tabular}

Table-VII. Recommended action prerequisites/necessity strategy for five levels of seriousness

\begin{tabular}{|c|c|c|}
\hline $\begin{array}{l}\text { Seriousness } \\
\text { level/Risk } \\
\text { score }\end{array}$ & Risk factors & Actions required \\
\hline \multirow[t]{6}{*}{$\begin{array}{l}\text { Category } 4 \\
\text { Rating } 0.7740 \\
-0.9536\end{array}$} & \multirow[t]{6}{*}{ Not recognized } & $\begin{array}{l}\text { Prompt notice is needed by } \\
\text { risk proprietor to Risk } \\
\begin{array}{l}\text { Management TL with } \\
\text { appropriate documents. }\end{array} \\
\end{array}$ \\
\hline & & $\begin{array}{l}\text { Prompt examination is needed } \\
\text { by Risk Management TL. }\end{array}$ \\
\hline & & Decision group is put on alert. . \\
\hline & & $\begin{array}{l}\text { An action strategy is described } \\
\text { and executed quickly to } \\
\text { remove or reduce the risk. }\end{array}$ \\
\hline & & $\begin{array}{l}\text { Risk Management TL tracks } \\
\text { action strategy consequences. }\end{array}$ \\
\hline & & $\begin{array}{l}\text { Risk board audits action } \\
\text { strategy outcomes every } \\
\text { month. }\end{array}$ \\
\hline \multirow[t]{4}{*}{$\begin{array}{l}\text { Category } 3 \\
\text { Rating } 0.4954 \\
-0.7739\end{array}$} & \multirow[t]{4}{*}{$\mathrm{H}_{11}, \mathrm{H}_{21}, \mathrm{H}_{23}, \mathrm{H}_{25}, \mathrm{H}_{41}, \mathrm{H}_{43}$} & $\begin{array}{l}\text { Prompt examination is } \\
\text { required by the Risk } \\
\text { Management TL. }\end{array}$ \\
\hline & & $\begin{array}{l}\text { Rapid action required (within } \\
1-2 \text { days). }\end{array}$ \\
\hline & & $\begin{array}{l}\text { Decision group surveys, } \\
\text { consents and additionally } \\
\text { modify action strategy to } \\
\text { remove or reduce risks to be as } \\
\text { low as possible. }\end{array}$ \\
\hline & & $\begin{array}{l}\text { Risk board audits action } \\
\text { strategy outcomes every } \\
\text { month. }\end{array}$ \\
\hline \multirow[t]{5}{*}{$\begin{array}{l}\text { Category } 2 \\
\text { Rating } 0.4305 \\
-0.4953\end{array}$} & \multirow[t]{5}{*}{$\begin{array}{l}\mathrm{H}_{22}, \mathrm{H}_{24}, \mathrm{H}_{31}, \mathrm{H}_{32}, \mathrm{H}_{41}, \\
\mathrm{H}_{44}, \mathrm{H}_{45},\end{array}$} & $\begin{array}{l}\text { Risk proprietor essential to } \\
\text { inform risk to Risk } \\
\text { Management TL. }\end{array}$ \\
\hline & & $\begin{array}{l}\text { Risk Management group } \\
\text { explores risk in a convenient } \\
\text { way. }\end{array}$ \\
\hline & & Action strategy is resolved. \\
\hline & & $\begin{array}{l}\text { Action needed within a week } \\
\text { to remove/reduce risks as } \\
\text { much as possible by the risk } \\
\text { proprietor. }\end{array}$ \\
\hline & & $\begin{array}{l}\text { Risk board audits action } \\
\text { strategy outcomes every } \\
\text { month. }\end{array}$ \\
\hline
\end{tabular}




\begin{tabular}{|c|c|c|}
\hline \multirow[t]{3}{*}{$\begin{array}{l}\text { Category } 1 \\
\text { Rating } 0.2237 \\
-0.4304\end{array}$} & \multirow[t]{3}{*}{$\mathrm{H}_{12}, \mathrm{H}_{33}, \mathrm{H}_{51}, \mathrm{H}_{52}}$, & $\begin{array}{l}\text { Distinctive examination is } \\
\text { needed by Risk Management } \\
\text { TL. }\end{array}$ \\
\hline & & $\begin{array}{l}\text { Action strategies described to } \\
\text { reduce risk as little as sensibly } \\
\text { feasible. Action needed within } \\
\text { a sensible timespan ( } 2-4 \\
\text { weeks). }\end{array}$ \\
\hline & & $\begin{array}{l}\text { Risk can be studied and } \\
\text { assessed at risk board meeting } \\
\text { every month. }\end{array}$ \\
\hline \multirow{3}{*}{$\begin{array}{l}\text { Category 0 } \\
\text { Rating } 0.0000 \\
-0.2236\end{array}$} & \multirow[t]{3}{*}{ Not identified } & No action needed. \\
\hline & & $\begin{array}{l}\text { Risk put on watch list and } \\
\text { audited by risk board. }\end{array}$ \\
\hline & & $\begin{array}{l}\text { Risk can be followed for } \\
\text { assistance if risk rating } \\
\text { enlarges. }\end{array}$ \\
\hline
\end{tabular}

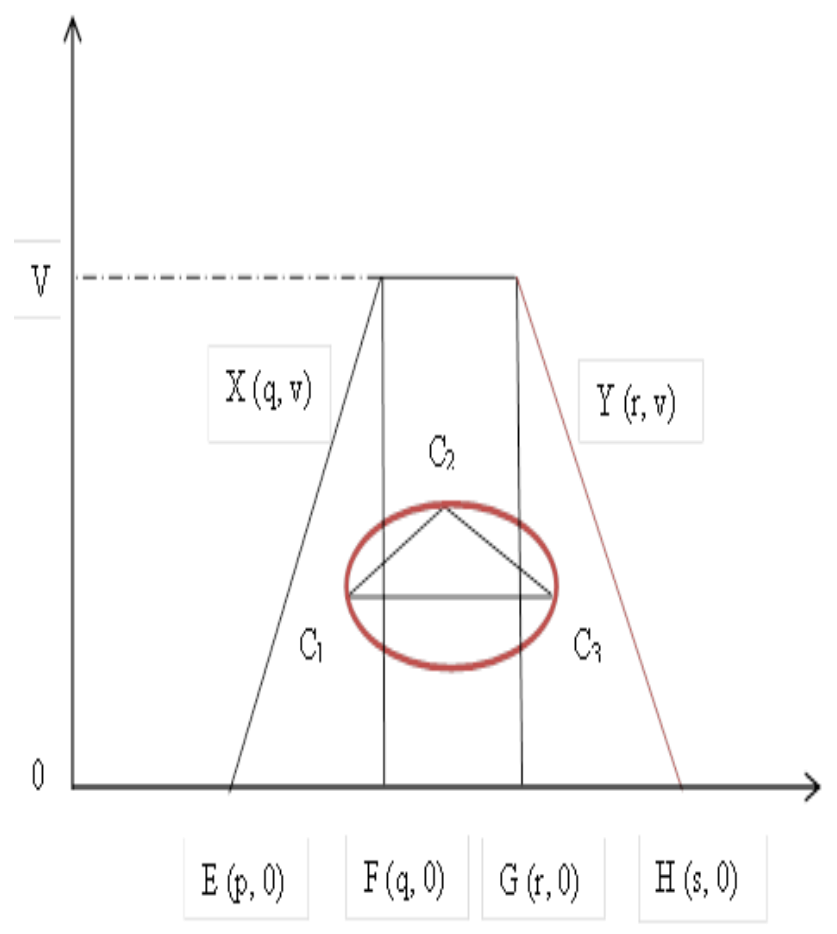

Fig. 1. Circumcentre of Centroid

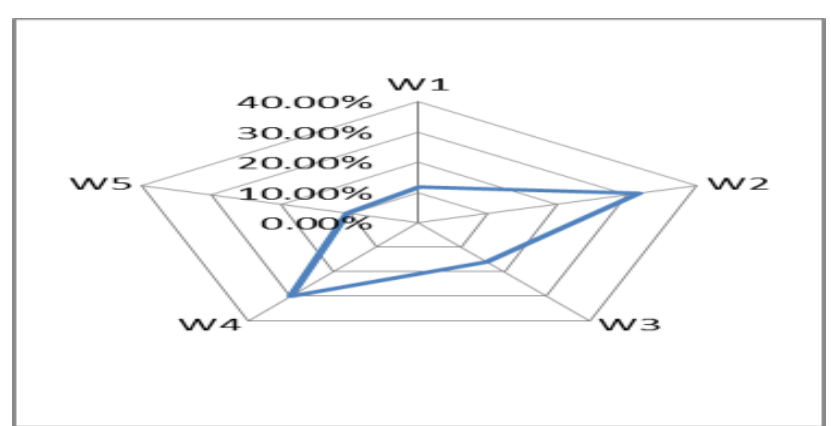

Fig. 2. Proportion of commitment of different risk aspects to general project risk

\section{REFERENCES}

1. M. W. Cohen and G. R. Palmer, "Project risk identification and management," AACE International Transactions, 2004, IN11.

2. B. S. Dhillon, "Methods for performing human reliability and error analysis in health care," International Journal of Health Care Quality Assurance, vol. 16(6), 2003, 306-317.

3. R. Flin, J. Winter, M. R. Cakil Sarac, "Human factors in patient safety: review of topics and tools," World Health, 2009, 2.
4. A. Gawanmeh, H. Al-Hamadi, M. Al-Qutayri, S. K. Chin, K. Saleem, "Reliability analysis of healthcare information systems: State of the art and future directions," In E-health Networking, Application \& Services (HealthCom), 2015 17th International Conference on (pp. 68-74). IEEE.

5. Q. L. Lin, D. J. Wang, W. G. Lin, H. C. Liu, "Human reliability assessment for medical devices based on failure mode and effects analysis and fuzzy linguistic theory," Safety science,Vol. 62, 2014 248-256.

6. J. Reason, "Human error: models and management,". Bmj, Vol. 320(7237), 2000, 768-770.

7. S. Muthuperumal, P. Titus, M. Venkatachalapathy, "A STUDY ON SOLVING GENERALIZED TRAPEZOIDAL FUZZY TRANSPORTATION PROBLEM WITH MIXED CONSTRAINTS USING RANKING FUNCTION," 2018.

8. A. Kumar, P. Singh, A. Kaur, P. Kaur, "Ranking of generalized trapezoidal fuzzy numbers based on rank, mode, divergence and spread," Turkish Journal of Fuzzy Systems, Vol. 1(2), 2010, 141-152.

9. C. Samantra, S. Datta, S. S. Mahapatra, "Fuzzy based risk assessment module for metropolitan construction project: An empirical study". Engineering Applications of Artificial Intelligence, Vol. 65, 2017, 449-464.

10. British Standards Institution, BS OHSAS 18002: 2008 Occupational Health and Safety Management Systems: Guidelines for the Implementation of OHSAS 18001: 2007. British Standards Institution, 2008.

11. L. A. Zadeh, "Fuzzy sets". Information and control, Vol. 8(3), 1965, 338-353.

12. P. Rao and N. R. Shankar, "Ranking fuzzy numbers with a distance method using circumcenter of centroids and an index of modality," Advances in Fuzzy Systems, 2011, 3.

\section{AUTHORS PROFILE}

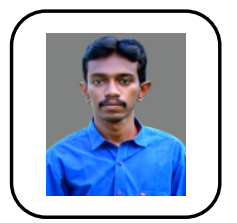

R.K.A.Bhalaji obtained his B.E from the K.L.N.College of Engineering, Madurai, Tamilnadu, India. He completed his M.Tech in Industrial Safety Engineering in 2016 at the Kalasalingam Academy of Research and Education, Krishnankoil, Tamilnadu, India. Currently, he is a Research Scholar in the Department of Mechanical Engineering, Kalasalingam Academy of Research and Education, Krishnankoil, Tamilnadu, India. His research interests include multi-criteria decision making and application of fuzzy set theory in real life decision problems. He is currently pursuing PHD in the area of analysis of risk factors for the identification and evaluation for finding influential risk factors in healthcare industries by using MCDM methods. .

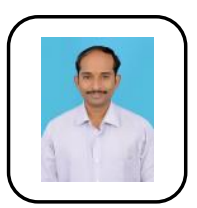

Dr.S.Bathrinath is an Associate Professor in the Department of Mechanical Engineering, Kalasalingam Academy of Research and Education, Krishnankoil, Tamilnadu, India. His current area of research includes multi-criteria decision making, scheduling \& optimization, soft computing and Artificial intelligence. He has published a number of papers in journal of national/international repute and presented a number of papers in various conferences/symposia in India and abroad. $\mathrm{He}$ is presently guiding a number of master/doctoral research scholars. Dr.S.Bathrinath is the corresponding author and can be contacted at: bathri@gmail.com

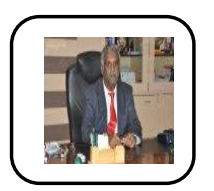

Dr.S.Saravanasankar is a Senior Professor in the Department of Mechanical Engineering, Kalasalingam Academy of Research and Education, Krishnankoil, Tamilnadu, India. $\mathrm{He}$ has more than 20 years of experience in teaching and research. His current area of research includes scheduling, optimization and multi-criteria decision making. He has published more than 40 research articles in journals of national and international repute. 
Table. VI: Aggregated fuzzy inclinations (Regarding risk probability and defect), calculated fuzzy risk score and corresponding risk scores

\begin{tabular}{|c|c|c|c|c|c|c|c|c|c|}
\hline $\begin{array}{l}\mathrm{W} \\
\mathrm{i}\end{array}$ & $\mathrm{H}_{\mathrm{ij}}$ & Probability $(\mathrm{P})$ & Effect of risk (I) & $\begin{array}{l}\text { Fuzzy risk score } \\
(\mathrm{P} \times \mathrm{E})\end{array}$ & $\mathrm{M}_{\mathrm{o}}$ & $\mathrm{N}_{\mathrm{o}}$ & $\begin{array}{l}\text { Crisp risk } \\
\text { score }\end{array}$ & $\begin{array}{l}\text { Positioning } \\
\text { order }\end{array}$ & $\begin{array}{l}\text { Risk } \\
\text { percentage }\end{array}$ \\
\hline \multirow[t]{2}{*}{$\begin{array}{l}\mathrm{W} \\
1\end{array}$} & $\mathrm{H}_{11}$ & $\begin{array}{l}(0.54,0.64,0.72,0.82 ; \\
1)\end{array}$ & $\begin{array}{l}(0.42,0.52,0.62,0.72 ; \\
1)\end{array}$ & $\begin{array}{l}(0.22,0.33,0.44,0.59 ; \\
1)\end{array}$ & $\begin{array}{l}0.395 \\
9 \\
\end{array}$ & $\begin{array}{l}0.387 \\
7 \\
\end{array}$ & 0.5541 & 2 & \multirow[t]{2}{*}{$\begin{array}{l}0.9776 \\
(11.96 \%)\end{array}$} \\
\hline & $\mathrm{H}_{12}$ & $\begin{array}{l}(0.12,0.28,0.38,0.46 \text {; } \\
1)\end{array}$ & $\begin{array}{l}(0.18,0.28,0.38,0.48 ; \\
1)\end{array}$ & $\begin{array}{l}(0.02,0.07,0.13,0.22 ; \\
1)\end{array}$ & $\begin{array}{l}0.112 \\
1\end{array}$ & $\begin{array}{l}0.408 \\
4\end{array}$ & 0.4235 & 15 & \\
\hline \multirow[t]{5}{*}{$\begin{array}{l}\mathrm{W} \\
2\end{array}$} & $\mathrm{H}_{21}$ & $\begin{array}{l}(0.58,0.68,0.74,0.84 ; \\
1)\end{array}$ & $\begin{array}{l}(0.38,0.48,0.58,0.68 ; \\
1)\end{array}$ & $\begin{array}{l}(0.22,0.32,0.42,0.57 ; \\
1)\end{array}$ & $\begin{array}{l}0.383 \\
8 \\
\end{array}$ & $\begin{array}{l}0.390 \\
9\end{array}$ & 0.5478 & 3 & \multirow{5}{*}{$\begin{array}{l}2.5993 \\
(31.82 \%)\end{array}$} \\
\hline & $\mathrm{H}_{22}$ & $\begin{array}{l}(0.36,0.46,0.48,0.52 ; \\
1)\end{array}$ & $\begin{array}{l}(0.26,0.36,0.46,0.56 ; \\
1)\end{array}$ & $\begin{array}{l}(0.09,0.16,0.22,0.29 ; \\
1)\end{array}$ & $\begin{array}{l}0.192 \\
9 \\
\end{array}$ & $\begin{array}{l}0.408 \\
7 \\
\end{array}$ & 0.4520 & 11 & \\
\hline & $\mathrm{H}_{23}$ & $\begin{array}{l}\text { (0.46,0.56,0.62,0.72; } \\
1)\end{array}$ & $\begin{array}{l}(0.42,0.52,0.62,0.72 ; \\
1)\end{array}$ & $\begin{array}{l}(0.19,0.29,0.38,0.51 ; \\
1)\end{array}$ & $\begin{array}{l}0.343 \\
8 \\
\end{array}$ & $\begin{array}{l}0.394 \\
9 \\
\end{array}$ & 0.5236 & 5 & \\
\hline & $\mathrm{H}_{24}$ & $\begin{array}{l}(0.44,0.54,0.58,0.68 \\
1)\end{array}$ & $\begin{array}{l}(0.34,0.44,0.54,0.64 ; \\
1)\end{array}$ & $\begin{array}{l}(0.14,0.23,0.31,0.43 ; \\
1)\end{array}$ & $\begin{array}{l}0.281 \\
0\end{array}$ & $\begin{array}{l}0.400 \\
8\end{array}$ & 0.4895 & 7 & \\
\hline & $\mathrm{H}_{25}$ & $\begin{array}{l}(0.46,0.56,0.62,0.72 ; \\
1)\end{array}$ & $\begin{array}{l}(0.58,0.68,0.78,0.88 \\
1)\end{array}$ & $\begin{array}{l}(0.26,0.38,0.48,0.63 ; \\
1)\end{array}$ & $\begin{array}{l}0.438 \\
2\end{array}$ & $\begin{array}{l}0.389 \\
4\end{array}$ & 0.5862 & 1 & \\
\hline \multirow[t]{3}{*}{$\begin{array}{l}\mathrm{W} \\
3\end{array}$} & $\mathrm{H}_{31}$ & $\begin{array}{l}(0.32,0.42,0.46,0.56 \\
1)\end{array}$ & $\begin{array}{l}(0.18,0.28,0.38,0.48 ; \\
1)\end{array}$ & $\begin{array}{l}(0.05,0.11,0.17,0.26 \\
1)\end{array}$ & $\begin{array}{l}0.151 \\
8\end{array}$ & $\begin{array}{l}0.407 \\
9\end{array}$ & 0.4352 & 13 & \multirow{3}{*}{$\begin{array}{l}1.308 \\
(16.01 \%)\end{array}$} \\
\hline & $\mathrm{H}_{32}$ & $\begin{array}{l}(0.36,0.46,0.48,0.58 ; \\
1)\end{array}$ & $\begin{array}{l}(0.22,0.32,0.42,0.52 ; \\
1)\end{array}$ & $\begin{array}{l}(0.07,0.14,0.20,0.30 ; \\
1)\end{array}$ & $\begin{array}{l}0.179 \\
7 \\
\end{array}$ & $\begin{array}{l}0.407 \\
6 \\
\end{array}$ & 0.4454 & 12 & \\
\hline & $\mathrm{H}_{33}$ & $\begin{array}{l}(0.28,0.38,0.44,0.54 \\
1)\end{array}$ & $\begin{array}{l}(0.14,0.24,0.34,0.44 ; \\
1)\end{array}$ & $\begin{array}{l}(0.03,0.09,0.14,0.23 \\
1)\end{array}$ & $\begin{array}{l}0.126 \\
4\end{array}$ & $\begin{array}{l}0.408 \\
4\end{array}$ & 0.4276 & 14 & \\
\hline \multirow[t]{5}{*}{$\begin{array}{l}\text { W } \\
4\end{array}$} & $\mathrm{H}_{41}$ & $\begin{array}{l}(0.44,0.54,0.58,0.68 \\
1)\end{array}$ & $\begin{array}{l}(0.46,0.56,0.66,0.76 \\
1)\end{array}$ & $\begin{array}{l}(0.20,0.30,0.38,0.51 ; \\
1)\end{array}$ & $\begin{array}{l}0.348 \\
2\end{array}$ & $\begin{array}{l}0.397 \\
9\end{array}$ & 0.5288 & 4 & \multirow{5}{*}{$\begin{array}{l}2.438 \\
(29.84 \%)\end{array}$} \\
\hline & $\mathrm{H}_{42}$ & $\begin{array}{l}(0.36,0.46,0.48,0.58 \\
1)\end{array}$ & $\begin{array}{l}(0.38,0.48,0.58,0.68 ; \\
1)\end{array}$ & $\begin{array}{l}(0.13,0.22,0.27,0.39 ; \\
1)\end{array}$ & $\begin{array}{l}0.254 \\
9\end{array}$ & $\begin{array}{l}0.405 \\
1\end{array}$ & 0.4787 & 8 & \\
\hline & $\mathrm{H}_{43}$ & $\begin{array}{l}(0.46,0.56,0.62,0.72 ; \\
1)\end{array}$ & $\begin{array}{l}(0.34,0.44,0.54,0.64 ; \\
1)\end{array}$ & $\begin{array}{l}(0.15,0.24,0.33,0.46 \\
1)\end{array}$ & $\begin{array}{l}0.296 \\
6 \\
\end{array}$ & $\begin{array}{l}0.397 \\
4\end{array}$ & 0.4959 & 6 & \\
\hline & $\mathrm{H}_{44}$ & $\begin{array}{l}(0.32,0.42,0.46,0.56 ; \\
1)\end{array}$ & $\begin{array}{l}(0.42,0.52,0.62,0.72 ; \\
1)\end{array}$ & $\begin{array}{l}(0.13,0.21,0.28,0.40 \\
1)\end{array}$ & $\begin{array}{l}0.257 \\
4 \\
\end{array}$ & $\begin{array}{l}0.403 \\
2 \\
\end{array}$ & 0.4784 & 9 & \\
\hline & $\mathrm{H}_{45}$ & $\begin{array}{l}(0.26,0.36,0.40,0.50 \\
1)\end{array}$ & $\begin{array}{l}(0.38,0.48,0.58,0.68 \text {; } \\
1)\end{array}$ & $\begin{array}{l}(0.09,0.17,0.23,0.34 \text {; } \\
1)\end{array}$ & $\begin{array}{l}0.208 \\
0\end{array}$ & $\begin{array}{l}0.405 \\
9\end{array}$ & 0.4561 & 10 & \\
\hline \multirow[t]{2}{*}{$\begin{array}{l}\mathrm{W} \\
5\end{array}$} & $\mathrm{H}_{51}$ & $\begin{array}{l}(0.14,0.24,0.28,0.38 ; \\
1)\end{array}$ & $\begin{array}{l}(0.18,0.28,0.38,0.48 ; \\
1)\end{array}$ & $\begin{array}{l}(0.02,0.06,0.10,0.18 ; \\
1)\end{array}$ & $\begin{array}{l}0.092 \\
4 \\
\end{array}$ & $\begin{array}{l}0.412 \\
1 \\
\end{array}$ & 0.4223 & 17 & \multirow[t]{2}{*}{$\begin{array}{l}0.8453 \\
(10.34 \%)\end{array}$} \\
\hline & $\mathrm{H}_{52}$ & $\begin{array}{l}(0.12,0.22,0.24,0.34 \\
1)\end{array}$ & $\begin{array}{l}(0.22,0.32,0.42,0.52 \\
1)\end{array}$ & $\begin{array}{l}(0.02,0.07,0.10,0.17 ; \\
1)\end{array}$ & $\begin{array}{l}0.090 \\
9 \\
\end{array}$ & $\begin{array}{l}0.413 \\
0 \\
\end{array}$ & 0.4229 & 16 & \\
\hline & & & & & & & 8.168 & & \\
\hline
\end{tabular}

